\title{
Size and growth of the crabeater seal Lobodon carcinophagus (Mammalia: Carnivora)
}

\author{
R. M. Laws ${ }^{1}$, A. Baird ${ }^{2}$ and M. M. Bryden ${ }^{3 *}$ \\ ${ }^{1}$ 3, The Footpath, Coton, Cambridge CB3 7PX, U.K. \\ 2 , Whitecote Drive, Bicton Heath, Shrewsbury, Shropshire SY3 5DB, U.K \\ ${ }^{3}$ Australian Marine Mammal Research Centre, Building B01, University of Sydney, Sydney, NSW 2006, Australia \\ (Accepted 21 May 2002)
}

\begin{abstract}
Growth in length and weight of a large sample of crabeater seals Lobodon carcinophagus collected over the period $1967-78$ is reported. Growth in dorsal standard length of 1146 seals ( 490 males, 656 females) from 0.5 to 20 years of age was similar to the pattern seen in other phocid seals. Length was plotted against age and Gompertz curves fitted to the data. Growth rates were estimated from the derived equations: males, $y=231.9-58.7 e^{-0.55 t}$; females, $y=236.8-63.6 e^{-0.44 t}$. The asymptote is at approximate length $234 \mathrm{~cm}$ and age 10 years in both males and females. Body weights were recorded for 249 seals aged from 0.5 to 20 years, of which reliable age estimates for 230 (100 males, 130 females) were available. Rates of growth in body weight were estimated from the derived equations: males, $y=200.0-94.1 e^{-0.48 t}$; females $y=212.4-116.2 e^{-0.40 t}$. The best estimate of body weight from linear body measurements is obtainable from a predictive equation relating body weight, length and axillary girth, determined by maximum likelihood: $W=0.000046 L G^{2}$ ( $W$, body weight; $L$, dorsal standard length; $G$, axillary girth). There was no significant difference between the sexes. Seasonal variations in body condition could not be determined because all animals were sampled in February and March. However, inter-year differences in recovery of body condition of adults, following the demands of breeding and moulting in the spring and summer, were observed. The data represent a unique time series covering the 1960s and 1970s. In terms of global climate change they should provide a valuable baseline for future studies.
\end{abstract}

Key words: Lobodon carcinophagus, size, growth

\section{INTRODUCTION}

Crabeater seals Lobodon carcinophagus are confined for the most part to the southern pack ice. They are believed to be the most abundant of all seals, although there are few estimates of total population size. The difficulty of estimating the total world population, distributed as it is over the vast area of the southern pack ice, is illustrated by the enormous range of estimates: from $2-5$ million (Scheffer, 1958) to as high as 50-75 million (Erickson et al., 1971). The most extensive and controlled censuses were done in the 1970s and early 1980s by Erickson's group, although the surveys were still of limited areas with extrapolation to the entire circumpolar pack ice area. Gilbert \& Erickson (1977) revised the earlier estimated world population of Erickson et al. (1971) downward to about 15 million, and following an analysis of all census data accrued between 1968 and 1983, Erickson

*All correspondence to: M. M. Bryden, 55 Central Avenue, St Lucia, Queensland 4067, Australia.
\& Hanson (1990) revised this down further to a minimum of 7 million.

As a result of their wide distribution and relative difficulty of access, little is known of the pattern of growth and development of this species. Laws (1958) published data relating length and age (estimated from examination of canine tooth sections) for 75 crabeater seals (34 females, 39 males, two sex unknown) collected at the northern end of the Antarctic Peninsula. Bryden \& Erickson (1976) recorded body size (lengths and weights) of 17 crabeater seals (eight females and nine males) ranging in estimated age from 3 months to 9 years. Like other phocid seal species, early postnatal growth of crabeater seals is rapid during the brief lactation period (Shaughnessy \& Kerry, 1989; Green et al., 1993): standard body length increases from 138 to $150 \mathrm{~cm}$, and body weight increases from 30 to $95 \mathrm{~kg}$, in the 17 days between birth and weaning. In his review of growth in pinnipeds McLaren (1993) drew on the data of Laws (1958) to provide information on growth of crabeater seals, and pointed out that they were the only extensive 
published data on sizes of individual crabeater seals of known age (estimated from examination of dentine in canine tooth sections). Apart from growth data included in the paper reporting aspects of reproduction by Bengtson $\&$ Siniff (1981), that situation has remained until now. This paper reports size and growth of a large sample of crabeater seals in the region of the Antarctic Peninsula between 1967 and 1978, for which a much improved method of age estimation from cementum layers in postcanine teeth was available (Laws, Baird \& Bryden, 2002).

\section{MATERIALS AND METHODS}

\section{Study area}

The crabeater seals of this study were taken in Marguerite Bay, on the west side of the Antarctic Peninsula (approximately $68^{\circ} \mathrm{S}, 68^{\circ} \mathrm{W}$ ). It is a large bay, encompassing fjords, channels and islands, surrounded by glaciers and mountains to $1500 \mathrm{~m}$. It freezes over in the autumn but retains variable amounts of pack ice and fast ice in the summer months.

\section{Animals}

All data were collected between 1967 and 1978 from seals killed for dog food, permitted at the time under Agreed Measures and permits issued by British Antarctic Survey Base Commanders at Stonington, Adelaide and Rothera stations (see Laws et al., 2002). Seals lying on ice floes in the bay were approached in a launch or inflatable boat lowered from a ship, and killed by a single shot to the brain using .303 rifles at short range. Shooting was from launch or inflatable boat if seals were on small floes, but if the floe was large enough the marksman would land on the floe and shoot there. The dates of collecting were not planned, but were determined by the ship's itinerary, which in turn was influenced by logistical needs of resupplying the Antarctic stations. The areas of operation were influenced by the distribution of the seals, which depended on the pack ice distribution.

All seals were collected in the period early February to late March. Although seasonal variations in body condition could not be included in the sampling by collecting during such a restricted period of the year, there were advantages. Sex ratios are likely to have been representative of absolute sex ratios of the entire population, immature animals are likely to have been less segregated, and body weight would have been less variable than during the breeding season, which is confined to October-November (Siniff et al., 1979; Shaughnessy \& Kerry, 1989). (Females probably lose $50 \%$ of their body weight during lactation, and males lose significant proportions of weight as they attend breeding cows and fight off rivals.)

\section{Data collection}

Usually there was no professional biologist on the ship, so data recorded and samples collected were restricted and simplified. Most seals killed were towed to the ship by the launch, and measurement of linear body dimensions, body weights and sample collection were done on deck. In some years these procedures were done on the floes. In all years, date, location and sex of animals were recorded. The following linear dimensions were measured: (a) dorsal standard length $^{1}$ (in the early years to the nearest half inch, thereafter to the nearest $\mathrm{cm}$ ) for 1350 animals of which 1146 were reliably aged from postcanine teeth (Laws et al., 2002); (b) in 2 years only, 1976 and 1977, axillary girth (American Society of Mammalogists, 1967) to the nearest $\mathrm{cm}$ for 162 animals (60 males, 102 females); (c) blubber thickness over the sternum, to the nearest $0.5 \mathrm{~cm}$ in 458 animals (159 males, 299 females) in the 4 years 1969 to 1972 . Body weight of 230 seals $(100$ males, 130 females) was recorded (in the years 1975, 1976 and 1977 only) to the nearest $0.5 \mathrm{~kg}$ using a heavy-duty spring balance suspended from the ship's derrick and raised by a winch. Mandibles were collected and ages were estimated later as described by Laws et al. (2002).

The raw data on which the paper is based are archived at the British Antarctic Survey, Madingley Road, Cambridge CB3 OET, U.K.

\section{RESULTS}

\section{Dorsal standard length}

The frequency distribution of dorsal standard length for 1350 seals (564 males, 786 females) is shown in Fig. 1. A preliminary analysis revealed that inter-annual variation was present in the frequency distribution of dorsal standard length. Figure 2 shows that, of the 9 years of data (1969 to 1977), mean length of seals 13-20 years old was greater in 1973, 1975 and 1976 than in the other years. Mean length of those males and females examined in 1973, 1975 and 1976 was $238 \mathrm{~cm}$ and $245 \mathrm{~cm}$, which was $5.1 \%$ and $5.2 \%$ greater than males and females in the remaining 6 years, respectively (analysis of variance, males 6 d.f., $F=13.604, P<0.001$; females 8 d.f., $F=$ $12.388, P<0.001)$. The results of analysis of variance tests applied to the 6- to 12-year age class were similar. Mean length of these males and females in the years 1973, 1975 and 1976 were $238 \mathrm{~cm}$ and $242 \mathrm{~cm}$ respectively, which were $4.5 \%$ and $4.7 \%$ greater than for the remaining years. Maximum length of males and females was $264 \mathrm{~cm}$ and $277 \mathrm{~cm}$, respectively. Figure 3 shows the relationship of dorsal standard length and age for the 1146 animals for which length was measured and age determined reliably

\footnotetext{
${ }^{1}$ Standard length, as defined by the American Society of Mammalogists (1967), is the straight-line length from the tip of the nose to the tip of the tail, with the animal lying on its back. The dorsal standard length was defined by McLaren (1993) as the straight-line length from nose to tail, measured with the animal lying on its venter.
} 


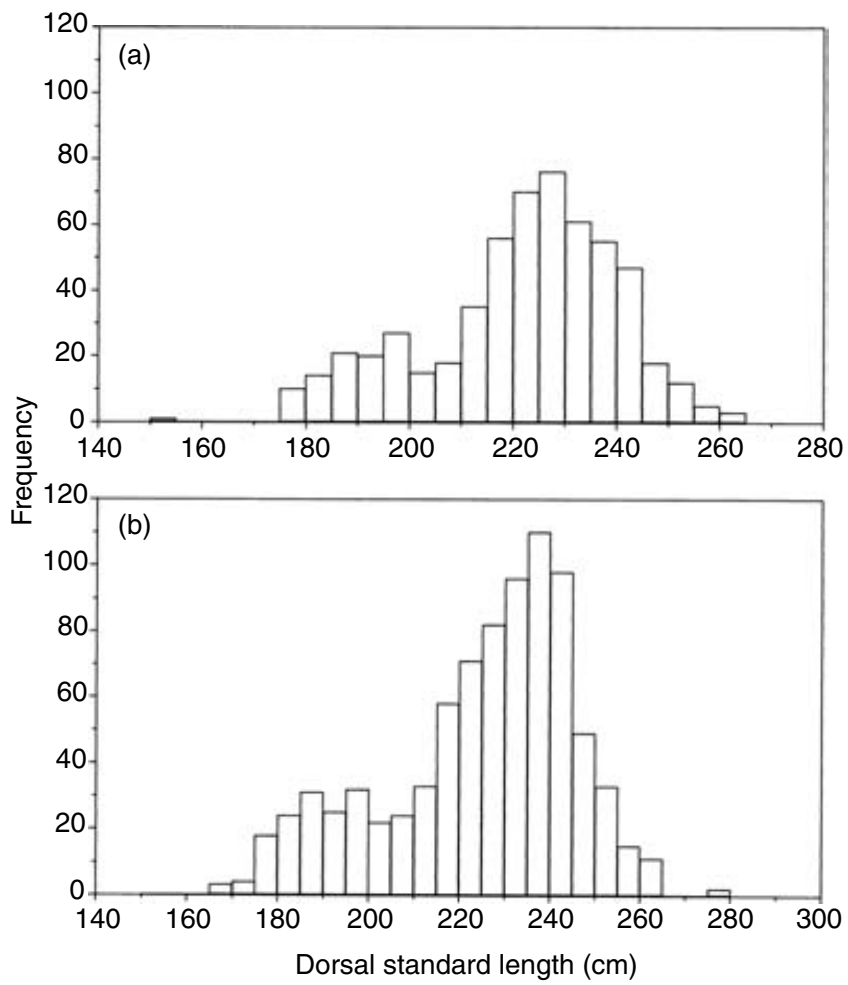

Fig. 1. Frequency distribution of dorsal standard length of 1350 crabeater seals Lobodon carcinophagus ((a) 564 males; (b) 786 females), in $5 \mathrm{~cm}$ classes. The single male in the $150-155 \mathrm{~cm}$ length group appears to be an exceptionally small animal with stunted growth.

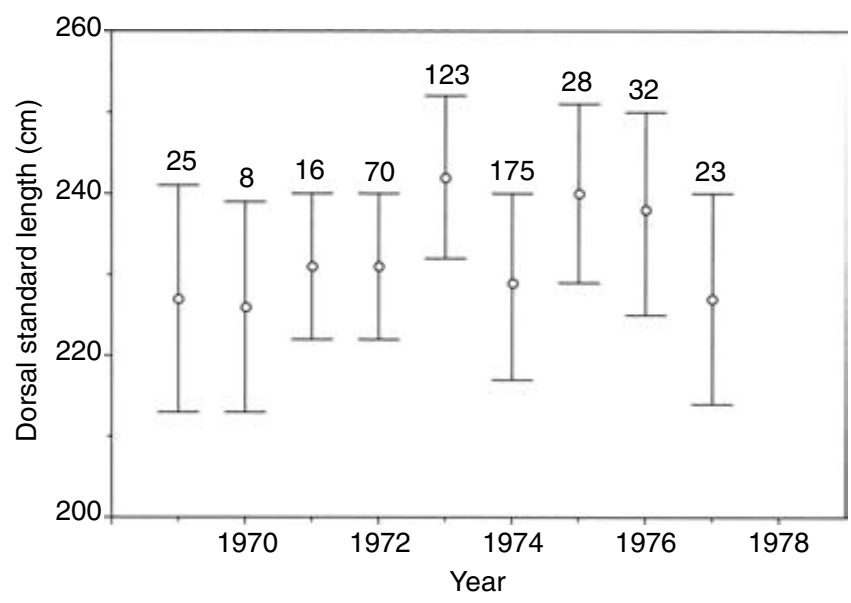

Fig. 2. Dorsal standard length (mean \pm SD) of crabeater seals Lobodon carcinophagus aged 13 years or more in the years 1969 to 1977 . The numbers indicate the number of animals $(n)$ for each year.

(490 males, 656 females). To determine whether there was any variation in growth rate between years, we compared data from 1969 to 1972 (cluster 1) and those from 1973 to 1977 (cluster 2) by maximum likelihood analysis using the Gompertz equation $y=a-b e^{-k t}$, where $y$ is length, $a$ is

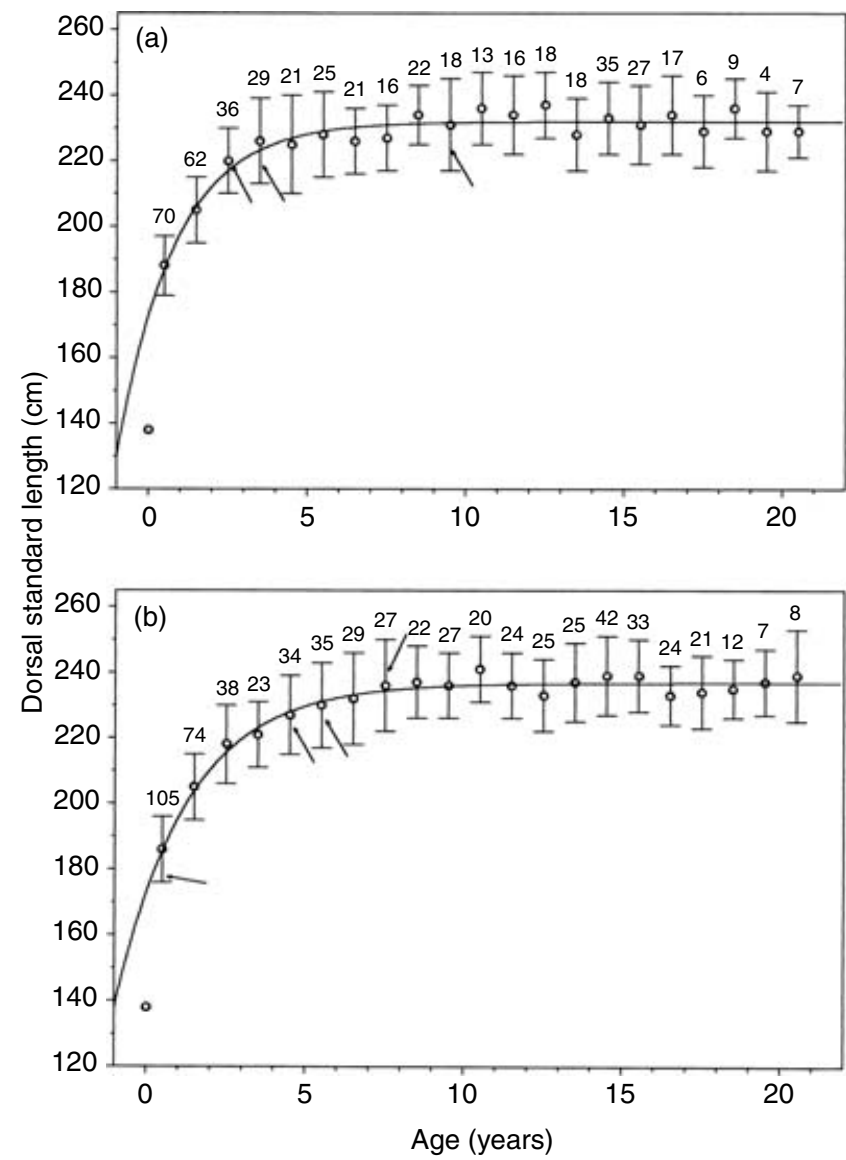

Fig. 3. Growth in dorsal standard length of 1146 crabeater seals Lobodon carcinophagus up to 20 years old ((a) 490 males and (b) 656 females) for which reliable age estimates were available. The arrows represent the lengths of individual animals from the Wilkes, Banzare and Sabrina coasts of Antarctica in 1973-74. The fitted lines were calculated using the Gompertz equation (but note that length at birth was taken from Shaughnessy \& Kerry (1989). Owing to the rapid growth from birth to weaning, the fitted curves do not intercept the ordinates at the neonatal value).

the asymptote, $b$ is integration constant, $k$ is growth rate, $t$ is age in years, and $e$ is the base of natural logarithms. Cluster 1 contained those years in which mean dorsal standard length did not differ from the overall mean, while cluster 2 contained 3 years in which mean length was greater than the overall mean $(1973,1975,1976)$. The ages of some animals in 1969 and 1970 were estimated from dorsal standard length only, and were not included in the analysis. Males and females were analysed separately, and only animals from $<1$ year to 8 years old were included because growth in length almost ceases by about the end of the seventh or eighth year of age (Fig. 3). Analysis of variance revealed that there was no significant difference between the clusters for either sex (males $F_{1,12}$ 1.41, N.S.; females $F_{1,12} 1.22$, N.S.). We also compared the asymptotes: for males the asymptotes were at $223 \mathrm{~cm}$ and $231 \mathrm{~cm}$ for clusters 1 and 2 , respectively $\left(F_{2,13}=2.01\right.$, N.S.), and for females the asymptotes were at $228 \mathrm{~cm}$ and 


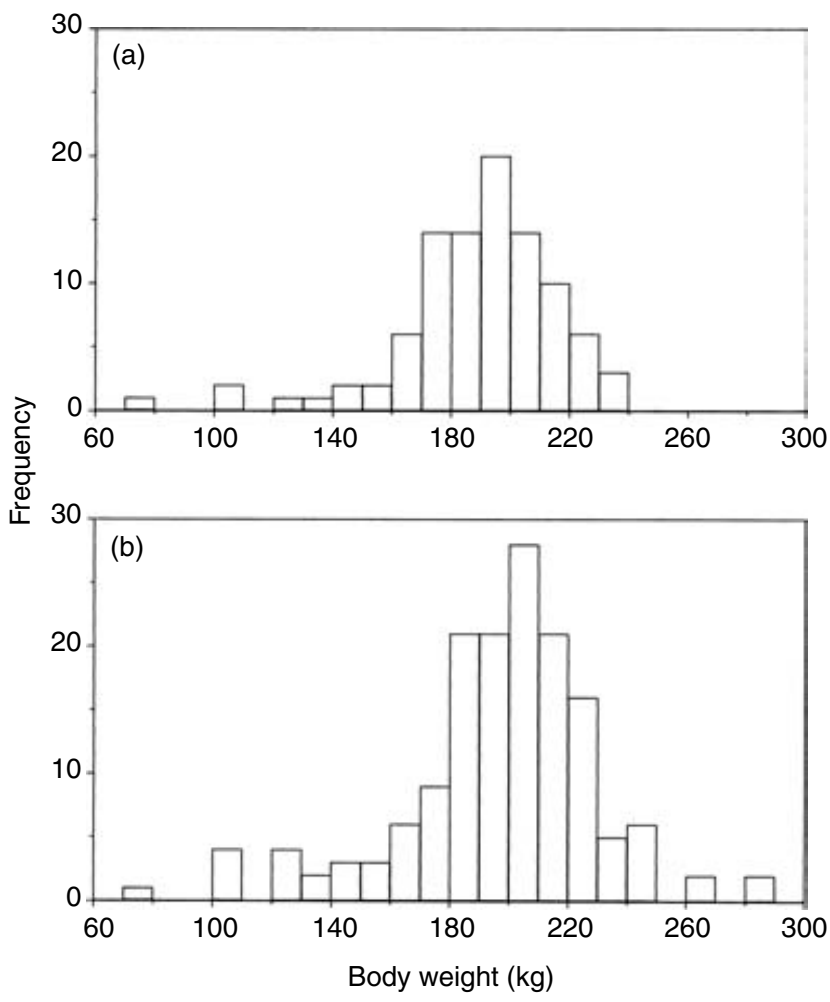

Fig. 4. Frequency distribution of body weight of 249 crabeater seals Lobodon carcinophagus ((a) 102 males, (b) 147 females) in $10 \mathrm{~kg}$ classes. The single male in the $71-80 \mathrm{~kg}$ class is the same animal that seemed exceptionally short (see Fig. 1).

$238 \mathrm{~cm}\left(F_{2,13}=14.8, P<0.01\right)$. The estimated growth rates for all animals to 20 years of age were calculated and fitted to the data in Fig. 3. The equations are:

$$
\begin{aligned}
\text { Males: } & y=231.9-58.7 e^{-0.55 t} \\
\text { Females: } & y=236.8-63.6 e^{-0.44 t}
\end{aligned}
$$

\section{Body weight and age}

The frequency distribution of body weights of those animals measured is shown in Fig. 4. Body weights were recorded in 3 years: in early February in 1976, late February in 1975 and early March in 1977. Mean weights of animals 13 years old or older differed among years: males 192, 203 and $208 \mathrm{~kg}$; females 205, 225 and $219 \mathrm{~kg}$, respectively, but these differences were not significant (males, $F=1.86,2$ d.f., $P>0.05$; females, $F=3.17$, d.f. $=2, P>0.05$ ) so the data were combined as shown in Fig. 5.

The estimated growth rate for all animals to 20 years of age, determined by application of the Gompertz equation, is fitted to the data in Fig. 5. The equations are:

Males: $\quad y=200.0-94.1 e^{-0.48 t}$

Females: $\quad y=212.4-116.2 e^{-0.40 t}$

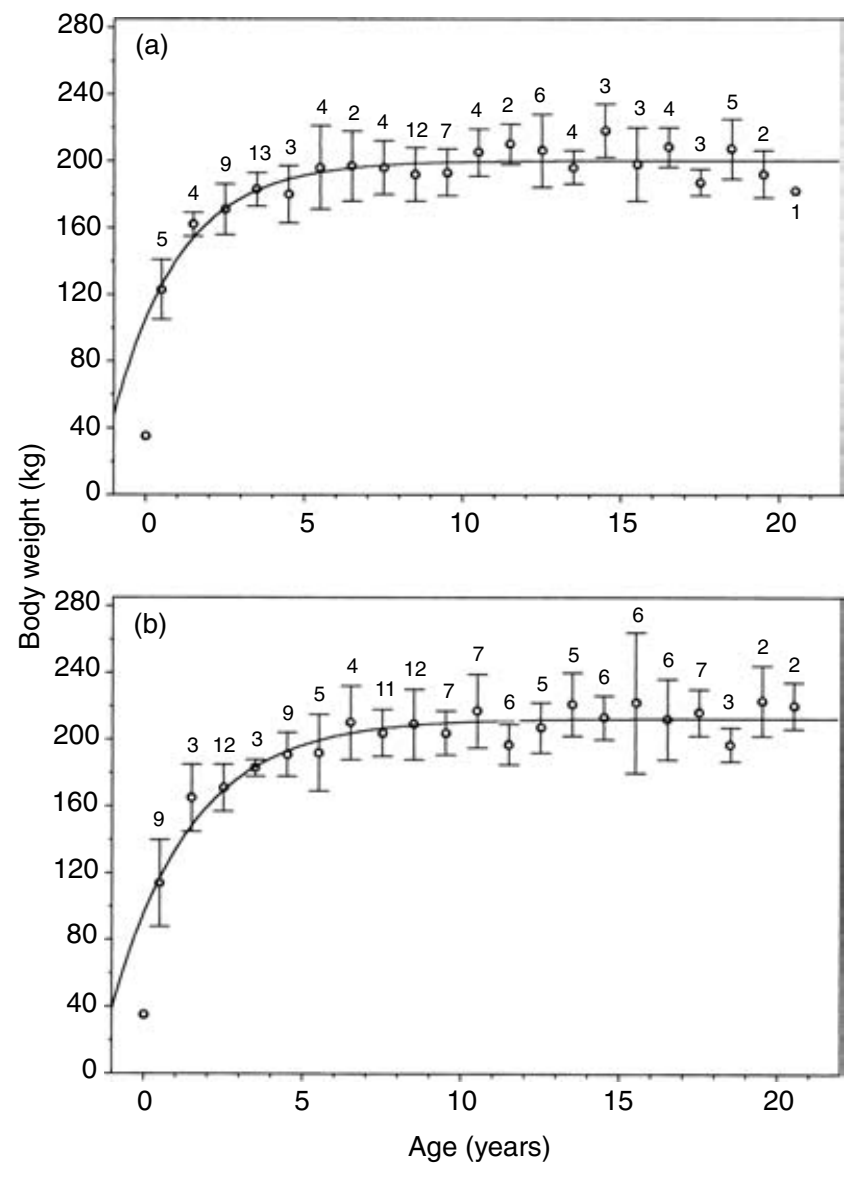

Fig. 5. Growth in body weight of 230 crabeater seals Lobodon carcinophagus ((a) 100 males and (b) 130 females) for which reliable age estimates were available. The fitted lines were calculated using the Gompertz equation, but note that the lightest pup reported is $36 \mathrm{~kg}$ (Shaughnessy \& Kerry, 1989). Because of the rapid growth from birth to weaning, the fitted curves do not intercept the ordinates at the neonatal value.

\section{Linear/weight relationships}

Axillary girths recorded in 1976 and 1977 ranged from 105 to $180 \mathrm{~cm}$ for 60 males, and from 105 to $175 \mathrm{~cm}$ for 102 females, modes approximately $135 \mathrm{~cm}$. The relationship between body weight and dorsal standard length for seals sampled between 1975 and 1977 can be expressed as:

$$
\begin{aligned}
& \text { Males }(n=102): \\
& \quad L=148+0.43 W(r=0.73, P<0.001) \\
& \text { Females }(n=147): \\
& \quad L=158.5+0.38 W(r=0.74, P<0.001)
\end{aligned}
$$

where $L$ is standard length in $\mathrm{cm}$, and $W$ is body weight in $\mathrm{kg}$.

The relationship of standard length, axillary girth and body weight was determined using the formulae $W=b L G^{2} \quad$ (Hoffman, 1975) and $\log W=a+b_{1} \log$ 
$L+b_{2} \log G$ (Usher \& Church, 1969). $W$ is body weight, $L$ is dorsal standard length, $G$ is axillary girth, and $a$ and $b$ are constants.

The formula judged to be least susceptible to variations in the data caused by either sex differences or year-toyear differences were determined by maximum likelihood (Bryden \& Erickson, 1976). As a result, Hoffman's (1975) equation was adopted. Analysis of variance was used to test for differences between the sexes and between years (1976 and 1977). This relationship can be expressed as: $W=0.000046 L G^{2}$, with no significant difference in slope between the sexes $\left(F_{3.156}=1.712, P>0.05\right)$. The percentage variation for each subgroup (sex, year) was: males (1976), 99.7\% (regression $F_{1.41}=13076.8$ ); males (1977), 99.1\% (regression $F_{1.17}=602.0$ ); females (1976), 99.8\% (regression $F_{1.58}=29707.7$ ); females (1977), 99.1\% (regression $F_{1.39}=2509.1$ ). All are highly significant $(P<0.01)$.

\section{Blubber thickness}

Mean blubber thickness of all animals measured was $3.28 \mathrm{~cm}$, increasing from approximately $2.7 \mathrm{~cm}$ in first year animals to $3.3 \mathrm{~cm}$ in the third year and 3.6 to $3.8 \mathrm{~cm}$ in adults. For animals measured in February and estimated to be in their first 5 years of postnatal life, there was no significant difference between the sexes $(F=0.67$, d.f. $=1, P>0.05)$ but the age effect was significant $(F=7.01$, d.f. $=3, P<0.001)$ (one-way analysis of variance with sex as covariate). Similar analysis of animals aged 4 to 36 years showed no significant difference between the sexes $(F=0.12$, d.f. $=1, P>0.05)$ or ages $(F=1.02$, d.f. $=26, P>0.05)$.

Mean blubber thickness of animals older than 3 years was $4.34 \mathrm{~cm}$ in March, which was significantly greater than in February when it was $3.41 \mathrm{~cm}(F=15.81$, d.f. $=$ 2, $P<0.001)$. In 1969 mean blubber thickness was $3.2 \mathrm{~cm}$ in February and $4.7 \mathrm{~cm}$ in March $(F=48.05$, d.f. $=1, P<0.001$ ), but between-year differences are indicated by the observation that in 1971, mean blubber thickness was $3.2 \mathrm{~cm}$ in February and $3.3 \mathrm{~cm}$ in March $(F=0.033$, d.f. $=1, P>0.05)$.

\section{DISCUSSION}

It has been possible to construct growth curves for crabeater seals from the data obtained in this study. Although all the data were collected during the summer, the curves for standard length reflects skeletal length and probably best describes the actual growth of the species (being less influenced by seasonal changes) at least for those that inhabit the region of the Antarctic Peninsula. The extent of movements and therefore mixing of crabeaters around the continent of Antarctica is not known, so it is not possible to say whether the data presented here are representative of crabeater seals as a whole. Body length and age of three male and four female crabeater seals from the pack ice of the Wilkes, Banzare and Sabrina coasts of Antarctica, and taken at approximately the same time of year (Bryden \& Erickson, 1976) fall within the range of the present sample (see arrows, Fig. 3). Although the numbers are small, they suggest that linear growth of crabeater seals might not differ greatly, if at all, from one region to another. The pattern of growth of crabeater seals is similar to that seen in other phocid seals, namely there is a rapid growth phase in early postnatal life (reported by Laws, 1958; Shaughnessy \& Kerry, 1989; McLaren, 1993) followed by slower growth for several years. The asymptote is at approximately 10 years in both males and females.

No single monotonic growth equation suffices for growth in length, which is linear before birth and remains so during early postnatal life (McLaren, 1993). The data of Shaughnessy \& Kerry (1989) show that, like other pinnipeds, crabeater seals exhibit considerable acceleration of growth during the nursing period, and the scant data relating to first-year animals suggest that there is relatively little further growth until the second year. The observation of differences in mean size of seals in different years is difficult to explain, although they might be due to errors of measurement. Because measurements were made by different people each year, and most of the observers were not trained biologists, the possibility exists that in those years when higher mean lengths were obtained, there was some departure from standard procedures, or simple inaccuracies in measurement occurred. Possible stretching of the measuring tapes was considered, but believed to be improbable because metal tapes were used. Possibly different populations were sampled in the 2-year clusters, but this seems unlikely and comparison of previous measurements of crabeater seals from different regions suggest that size differences between populations (if separate populations exist) are unlikely. However, this cannot be ruled out entirely. Because none of these explanations could be tested and the reason(s) for inter-year differences is unclear, no correction was made to the data prior to analysis.

The curves relating to body weight and age provide some information about overall annual body weight growth. They have the advantage of comparing animals of different ages at the same period of the year, and therefore probably of equivalent body condition, but the disadvantage of revealing nothing about the variation in body weight throughout the year. Although the observed differences in mean body weight between years were not statistically significant, such inter-annual differences are likely to occur, the major factor affecting them being food supply. The blubber thickness data suggest it: blubber thickness of animals older than 3 years increased from February to March in 1 year (1969) but not another (1971). An increase is expected, provided that food is abundant, because the sample would contain many seals of breeding age still regaining body condition lost during the previous breeding season. Comparison 
of blubber thickness measurements in February-March (present investigation) with those in September-October (Øritsland, 1970) suggest that body condition continues to increase through the winter. Average blubber thickness of adults in February-March was 3.6-3.8 cm (pers. obs.) and increased to an average in females of $5.7 \mathrm{~cm}$ in September and $6.7 \mathrm{~cm}$ in the first week of October. Loss of body condition in females occurred towards the end of October (mean blubber thickness $5.3 \mathrm{~cm}$ ), associated with suckling of young by some, and adult males also showed some decrease in blubber thickness during October although it was less than in the females (Øritsland, 1970).

We consider that these data are valuable for several reasons. The crabeater seal is the most abundant pinniped in the Southern Ocean and possibly the world, and now one of the largest consumers of Antarctic krill, yet we know very little about it. There has been an explosion of work on crabeater seal biology in recent years, which necessarily involves extensive and expensive logistical support, including estimating numbers, deploying satellite tags, and collecting tissue samples, as part of the Antarctic Pack Ice Seals (APIS) programme of the Scientific Committee on Antarctic Research (SCAR). The data reported here represent a unique time series covering the 1960 s and $1970 \mathrm{~s}$, and in view of the interest in global climate change they should provide an important baseline for future studies.

\section{Acknowledgements}

Many people were involved, over 12 years, in the collection of material in Antarctica for this study. They included ships' Masters, Officers and Seamen of the RRS John Biscoe, the British Antarctic Survey field staff ashore and afloat. They are too numerous to mention individually. Inigo Everson organized the first field collections, before research began on the material collected; Owen Darling assisted in the development of the laboratory methods and reading tooth layers in the early years; $\mathrm{C}$. Ricketts advised on statistical procedures; Chris Gilbert photographed specimens; Ken Schultz assisted with the preparation of the figures. To all participants in field or laboratory we extend our warm thanks. We thank two anonymous referees for helpful comments.

\section{REFERENCES}

American Society of Mammalogists, Committee on Marine Mammals (1967). Standard measurements of seals. J. Mammal. 48: 459-462.

Bengtson, J. L. \& Siniff, D. B. (1981). Reproductive aspects of female crabeater seals (Lobodon carcinophagus) along the Antarctic Peninsula. Can. J. Zool. 59: 92-102.

Bryden, M. M. \& Erickson, A. W. (1976). Body size and composition of crabeater seals (Lobodon carcinophagus), with observations on tissue and organ size in Ross seals (Ommatophoca rossi). J. Zool. (Lond.) 179: 235-247.

Erickson, A. W. \& Hanson, M. B. (1990). Continental estimates and population trends of Antarctic ice seals. In Antarctic ecosystems: ecological change and conservation: 253-264. Kerry, K. R. \& Hempel, G. (Eds). Berlin: Springer-Verlag.

Erickson, A. W., Siniff, D. B., Cline, D. R. \& Hoffman, R. J. (1971). Distributional ecology of Antarctic seals. In Proceedings of a symposium of Antarctic ice and water masses: 55-76. Sir George Deacon (Ed.). Brussels: Scientific Community Antarctic Research

Gilbert, J. R. \& Erickson, A. W. (1977). Distribution and abundance of seals in the pack ice of the Pacific sector of the Southern Ocean. In Adaptations within Antarctic ecosystems: 703-708. Llano, G. A. (Ed.). Washington, D.C.: Smithsonian Institution.

Green, B., Fogerty, A., Libke, J., Newgrain, K. \& Shaughnessy, P. (1993). Aspects of lactation in the crabeater seal (Lobodon carcinophagus). Aust. J. Zool. 41: 203-213.

Hoffman, R. J. (1975). Distribution patterns and population structure of Antarctic seals. Ph.D. thesis, University of Minnesota, USA.

Laws, R. M. (1958). Growth rates and ages of crabeater seals, Lobodon carcinophagus (Jacquinot and Pucheran). Proc. Zool. Soc. Lond. 130: 275-288.

Laws, R. M., Baird, A. \& Bryden, M. M. (2002). Age estimation in crabeater seals (Lobodon carcinophagus). J. Zool. (Lond.) 258: 197-204.

McLaren, I. A. (1993). Growth in pinnipeds. Biol. Rev. 68: 1-79.

Øritsland, T. (1970). Sealing and seal research in the south-west Atlantic pack ice, Sept-Oct 1964. In Antarctic ecology 1: 367376. Holdgate, M. W. (Ed.). London: Academic Press.

Scheffer, V. B. (1958). Seals, sea lions and walruses: a review of the pinnipedia. Stanford, California: Stanford University Press.

Shaughnessy, P. D. \& Kerry, K. R. (1989). Crabeater seals Lobodon carcinophagus during the breeding season: observations on five groups near Enderby Land, Antarctica. Mar. Mamm. Sci. 5: 68-77.

Siniff, D. B., Stirling, I., Bengtson, J. L. \& Reichle, R. A. (1979). Social and reproductive behavior of crabeater seals (Lobodon carcinophagus) during the austral spring. Can. J. Zool. 57: 22432255.

Usher, P. J. \& Church, M. (1969). On the relationship of weight, length and girth of the ringed seal (Pusa hispida) of the Canadian Arctic. Arctic 22: 120-129. 